\title{
Literasi Matematika Siswa IPS dalam Menyelesaikan Soal PISA Konteks Saintifik
}

\author{
Bagus Wahyu Purnomo', Anisa Fatwa Sari ${ }^{*}$ \\ Pendidikan Matematika, STKIP Al Hikmah Surabaya \\ Jambangan, Surabaya, Jawa Timur, Indonesia \\ 1baguswahyu987@gmail.com; ${ }^{2 *}$ anisa.fatwasari@gmail.com
}

Artikel diterima: 02-02-2021, direvisi: 22-09-2021, diterbitkan: 30-09-2021

\begin{abstract}
Abstrak
Hasil penelitian literasi matematika di Indonesia tidak secara spesifik mengungkap literasi matematika siswa dengan mempertimbangkan latar belakang keilmuan siswa. Penelitian ini bertujuan untuk mendeskripsikan kemampuan literasi matematika siswa IPS dalam menyelesaikan soal PISA. Literasi matematika yang diungkap berfokus pada pemahaman siswa IPS terhadap konteks saintifik. Penelitian deskriptif ini melibatkan 3 siswa IPS di salah satu SMA di Jawa Timur. Setiap subjek penelitian yang memiliki tingkat kemampuan matematika berbeda diberikan soal tes kemampuan literasi matematika kemudian diwawancarai. Hasil tes dan wawancara dianalisis menggunakan kerangka kerja PISA. Hasil penelitian menunjukkan bahwa siswa IPS memiliki tingkat pemahaman yang baik tentang konteks saintifik pada soal PISA. Dari 3 soal yang diberikan, siswa IPS hanya terkendala di satu soal sehingga tidak semua indikator pemahaman terhadap konteks PISA dapat dipenuhi oleh dua siswa.

Kata Kunci: konteks saintifik, literasi matematika, PISA.
\end{abstract}

\section{Mathematical Literacy of Social Studies Students in Solving PISA Questions in the Scientific Context}

\begin{abstract}
The results of research on mathematical literacy in Indonesia do not specifically reveal students' mathematical literacy by considering students' scientific backgrounds. This study aims to describe the mathematical literacy skills of social studies students in solving PISA questions. The mathematical literacy revealed focuses on the social studies students' understanding of the scientific context. This descriptive study involved 3 social studies students in one high school in East Java. Each research subject who has a different level of mathematical ability is given a mathematical literacy ability test question and then interviewed. The results of the tests and interviews were analyzed using the PISA framework. The results showed that social studies students had a good level of understanding of the scientific context on PISA questions. Of the 3 questions given, social studies students were only constrained in one question so that not all indicators of understanding the PISA context could be met by two students.

Keywords: scientific context, mathematical literacy, PISA.
\end{abstract}




\section{Pendahuluan}

Ukuran literasi matematika siswa hampir selalu didasarkan pada hasil PISA (Programme for International Student Assessment). PISA adalah program penilaian berskala internasional, untuk pelajar berusia 15 tahun, yang diselenggarakan oleh OECD (Organisation for Economic Co-operation and Development) per tiga tahun sejak tahun 2000. Selain literasi matematika, domain lain yang dinilai oleh PISA adalah literasi baca dan literasi sains.

PISA bertujuan untuk mengetahui sejauh mana kemampuan siswa dalam menggunakan pengetahuan yang dipelajari di sekolah untuk siap menjalani kehidupan sebagai bagian dari masyarakat (Junika, Izzati, \& Tambunan, 2020). Selain itu, kuesioner untuk tenaga pendidik, orangtua, dan siswa sebagai data pendukung dapat merepresentasikan keadaan pendidikan di negara peserta PISA. Jadi, hasil PISA dapat dijadikan acuan untuk mengevaluasi kebijakan pendidikan (Merpaung, 2006; Pratiwi, 2019).

Namun sejak pertama kali mengikuti PISA pada tahun 2000, Indonesia belum pernah mengalami peningkatan peringkat yang signifikan (OECD, 2001, 2004, 2007, 2010, 2013b, 2016). Bahkan hasil PISA tahun 2018 menunjukkan Indonesia berada di peringkat 10 terbawah dunia (OECD, 2019b). Skor literasi matematika siswa Indonesia adalah 379, sedangkan rata-ratanya adalah 489 .
Literasi matematika diukur dari kapasitas individu untuk merumuskan, menggunakan, dan menafsirkan matematika dalam berbagai konteks untuk menemukan solusi permasalahan (Maharani \& Abadi, 2019; OECD, 2019c). Siswa dari beragam latar belakang (jurusan, lingkungan rumah dan kondisi sekolah) seharusnya memiliki literasi matematika terutama setelah mencapai usia 15 tahun. Hal ini tentu juga berlaku pada siswa kelas $X$ IPS yang rata-rata usianya 15 tahun ke atas.

Sayangnya, hasil penelitian literasi matematika di Indonesia tidak secara spesifik mengungkap literasi matematika siswa dengan mempertimbangkan latar belakang keilmuan siswa. Beberapa penelitian telah mengungkap tentang literasi matematika yaitu analisis kemampuan literasi matematika berdasarkan kemampuan matematika (Muzaki \& Masjudin, 2019; Prabawati, 2018; Puspitasari, 2015), analisis kemampuan literasi matematika pada konten quantity (Noviana \& Murtiyasa, 2020), analisis kemampuan literasi dan rasa ingin tahu siswa pada PjBL oleh (Wicaksana dkk., 2017).

Hasil beberapa penelitian di atas menunjukkan bahwa kemampuan literasi matematika siswa Indonesia tergolong rendah. Namun, hasil yang ditunjukkan kurang mendalam sebab hanya menggunakan acuan standar penilaian PISA secara kuantitatif: correct, partially correct, incorrect. Eksplorasi lanjutan lebih 
spesifik yang melibatkan kategori soal PISA secara konteks, konten, proses dan kompetensi secara terpisah kurang diperhatikan.

Khusus tentang konteks PISA, latar belakang siswa sangat mungkin mempengaruhi literasi matematika mereka. Siswa IPS dan IPA yang belajar dengan kualifikasi kompetensi dasar berbeda mungkin memiliki pemahaman konteks yang berbeda. Apalagi soal matematika PISA memiliki beberapa kategori yaitu level (1-6), konteks (personal, occupational, societal, scientific), konten (change and relationship, space and shape, quantity, uncertainty and data), proses (formulate, employ, interprete), dan kompetensi (reproduction, connection, reflection). Konteks atau situasi yang diujikan pada soal PISA disajikan pada Tabel 1 (Dinni, 2018; Johar, 2012; Maharani \& Abadi, 2019; OECD, 2019a).

Tabel 1.

Konteks PISA

\begin{tabular}{|c|c|}
\hline Konteks & Deskripsi \\
\hline Personal & $\begin{array}{l}\text { Isi konteks ini meliputi hal- } \\
\text { hal yang berhubungan dengan } \\
\text { kegiatan pribadi siswa dalam } \\
\text { kehidupan sehari-hari. }\end{array}$ \\
\hline Occupational & $\begin{array}{l}\text { Konteks ini meliputi hal-hal } \\
\text { yang berkaitan dengan } \\
\text { kehidupan siswa di sekolah } \\
\text { dan atau di lingkungan tempat } \\
\text { bekerja. }\end{array}$ \\
\hline Societal & $\begin{array}{l}\text { Konteks ini meliputi hal-hal } \\
\text { yang berkaitan dengan } \\
\text { penggunaan pengetahuan } \\
\text { matematika dalam hidup } \\
\text { bermasyarakat. }\end{array}$ \\
\hline Scientific & Konteks ini meliputi hal-hal \\
\hline
\end{tabular}

yang berhubungan dengan kegiatan ilmiah bersifat abstrak menuntut pemahaman penguasaan teori dalam melakukan pemecahan masalah matematika.

Sekalipun konteks yang disajikan bersifat umum dan seharusnya lazim diketahui siswa, belum tentu siswa di Indonesia yang 'dipisah' berdasarkan ilmu sosial dan sains (kelas IPA dan IPS) akan mudah memahami konteks PISA. Siswa yang kurang atau tidak memahami konteks sangat mungkin kesulitan memilih pendekatan yang sesuai untuk masalah yang dihadapi. Kajian tentang pemahaman siswa terhadap konteks ketika memecahkan masalah menjadi penting.

Setiap siswa, termasuk siswa IPS, seharusnya memiliki pemahaman konteks saintifik yang cukup sebagai prasyarat hidup bermasyarakat. Jika tidak, siswa akan kesulitan mencerna beragam informasi seperti keperluan medis, memaknai perubahan iklim dan lingkungan, atau pemeliharaan hewan dan tumbuhan. Pemahanan siswa IPS terhadap konteks saintifik menjadi penting saat mereka menjadi individu dewasa.

Oleh karena itu, penelitian ini fokus mengenai analisis kemampuan literasi matematika siswa IPS dalam menyelesaikan soal PISA konteks saintifik. Lebih khusus, penelitian ini akan mendeskripsikan literasi matematika siswa IPS ditinjau dari aspek pemahaman terhadap konteks. 
Keunggulan lain dari penelitian ini yaitu: 1) sekolah yang dipilih sebagai objek penelitian belum pernah mengikuti PISA, 2) konten PISA yang dipilih sudah dikenal siswa IPS yaitu change and relationship dan quantity. Hasil penelitian diharapkan dapat mengungkap bagaimana kemampuan siswa IPS mengolah informasi dari konteks saintifik untuk menyelesaikan masalah PISA yang diberikan. Deskripsi pemahaman konteks saintifik soal PISA oleh siswa IPS dapat menjadi pertimbangan guru ketika mengintegrasikan konteks saintifik dalam pembelajaran matematika.

\section{Metode}

Jenis penelitian ini adalah kualitatif deskriptif karena sesuai dengan tujuan penelitian yaitu mendeskripsikan kemampuan literasi siswa IPS dalam menyelesaikan soal PISA konteks saintifik. Penelitian dilaksanakan di SMA Negeri 1 Purwosari, Kabupaten Pasuruan, Jawa Timur secara daring. Subjek dipilih dari 36 orang siswa IPS kelas $X$ dengan menggunakan teknik purposive sampling. Peneliti memilih 3 dari 36 siswa berdasarkan rekomendasi guru dengan kategori kemampuan matematika yaitu 1 siswa berkemampuan tinggi (S1), 1 siswa berkemampuan sedang (S2), dan 1 siswa berkemampuan rendah (S3).

Instrumen penelitian berupa soal matematika PISA pada konteks saintifik sebanyak 3 soal dan pedoman wawancara. Soal tersebut diambil dari PISA 2012
Released Mathematics Items (OECD, 2013a). Soal 1 dan 2 memuat konteks koloni penguin sementara soal 3 memuat tentang Pembangkit Tenaga Angin.

Soal 1: Penguin

Jean memperkirakan bagaimana jumlah koloni penguin akan berubah selama beberapa tahun mendatang.

Untuk menentukannya, dia membuat asumsi berikut:

- Pada awal tahun, koloni terdiri dari 10.000 penguin (5000 pasang).

- Setiap pasangan penguin memelihara satu anak pada musim semi setiap tahun.

- Pada akhir tahun, 20\% dari semua penguin (dewasa dan anak) akan mati.

Pada akhir tahun pertama, berapa banyak penguin (dewasa dan anak) yang ada di koloni?

\section{Soal 2: Penguin}

Jean berasumsi, koloni akan tumbuh mengikuti pola berikut:

- Setiap awal tahun, jumlah penguin jantan sama dengan jumlah penguin betina (penguin saling berpasangan).

- Setiap pasangan memiliki satu anak di musim panas setiap tahunnya.

- Setiap akhir tahun, 20\% dari semua penguin mati (dewasa dan anakanak).

- Penguin berusia satu tahun akan memiliki anak. 


\begin{tabular}{|l|}
\hline \multicolumn{3}{|c|}{ Berdasarkan asumsi di atas, manakah } \\
rumus yang cocok untuk \\
mendeskripsikan jumlah penguin $(P)$ \\
setelah 7 tahun? \\
A. $P=10000 \times(1,5 \times 0,2)^{7}$ \\
B. $P=10000 \times(1,5 \times 0,8)^{7}$ \\
C. $P=10000 \times(1,2 \times 0,2)^{7}$ \\
D. $P=10000 \times(1,2 \times 0,8)^{7}$ \\
\hline
\end{tabular}

Soal 3: Pembangkit Tenaga Angin

Kota Zed mempertimbangkan pembangunan pembangkit listrik tenaga angin. Dewan kota berkumpul dan mendapatkan informasi tentang model pembangkit sebagai berikut.

Model: E82

Tinggi: 138 Meter

Jumlah baling-baling: 3

Panjang tiap baling-baling: 40 meter

Kecepatan rotasi maksimal: 20 rotasi per menit

Biaya pembangunan: 3.200 .000 zeds

Omset: 0.10 zeds per kWh

Biaya perawatan: 0.01 zeds per kWh

Efisiensi: operasional 97\% per tahun

Berikut adalah pernyataan tentang pembangkit listrik tenaga angin e-28. Apa kesimpulan yang dapat diperoleh dari informasi yang disediakan? Silahkan lingkari pernyataan "benar" atau "salah"!

\section{Biaya pembangunan dari}

3 pembangkit listrik totalnya akan lebih dari

Benar/salah
Biaya perawatan untuk

pembangkit listrik sekitar

Benar/salah

$5 \%$ dari omset.

Biaya perawatan untuk

pembangkit listrik

tergantung jumlah kwh

Benar/salah

yang dihasilkan.

Selama 97 hari dalam

setahun, pembangkit

listrik tidak beroperasi.

Teknik pengumpulan data pada penelitian ini terdiri dari tes untuk mengumpulkan data dan wawancara untuk mengkonfirmasi data yang telah diperoleh dari hasil tes. Menurut OECD (2019a), terdapat 7 indikator untuk menentukan apakah siswa sudah menguasai suatu konteks pada soal PISA sebagaimana disajikan pada Tabel 2.

Tabel 2.

Indikator Konteks PISA

Communicating Read, decode, and make sense
of statements, questions,
tasks,

objects or images, in order to form a mental model of the situation.

\begin{tabular}{|c|c|}
\hline Mathematising & $\begin{array}{c}\text { Identify the underlying } \\
\text { mathematical variables and } \\
\text { structures in the real world } \\
\text { problem, and make } \\
\text { assumptions } \\
\text { so that they can be used. }\end{array}$ \\
\hline Representation & $\begin{array}{l}\text { Create a mathematical } \\
\text { representation of real-world } \\
\text { information. }\end{array}$ \\
\hline $\begin{array}{l}\text { Reasoning and } \\
\text { Argument }\end{array}$ & $\begin{array}{c}\text { Explain, defend or provide a } \\
\text { justification for the identified } \\
\text { or } \\
\text { devised a representation of a } \\
\text { real world situation. }\end{array}$ \\
\hline
\end{tabular}




\begin{tabular}{|c|c|}
\hline $\begin{array}{l}\text { Devising } \\
\text { Strategies for } \\
\text { Solving Problems }\end{array}$ & $\begin{array}{l}\text { Select or devise a plan or } \\
\text { strategy to mathematically } \\
\text { reframe contextualised } \\
\text { problems. }\end{array}$ \\
\hline $\begin{array}{l}\text { Using symbolic, } \\
\text { Formal and } \\
\text { Technical } \\
\text { Language and } \\
\text { Operations }\end{array}$ & $\begin{array}{c}\text { Use appropriate variables, } \\
\text { symbols, diagrams and } \\
\text { standard } \\
\text { models in order to represent a } \\
\text { real-world problem using } \\
\text { symbolic/formal language. }\end{array}$ \\
\hline $\begin{array}{l}\text { Using } \\
\text { Mathematical } \\
\text { Tools }\end{array}$ & $\begin{array}{l}\text { Use mathematical tools in } \\
\text { order } \\
\text { to recognise mathematical } \\
\text { structures or to portray } \\
\text { mathematical relationships. }\end{array}$ \\
\hline
\end{tabular}

\section{Hasil dan Pembahasan}

Ketiga siswa subjek penelitian menjawab soal 1 tentang penguin dengan benar. Ketiga subjek tidak menunjukkan perbedaan kemampuan dalam mengomunikasikan kembali informasi yang disajikan pada soal (communicating). Setiap subjek mendata dan menuliskan kembali informasi penting pada lembar jawaban mereka (lihat Gambar 1, 2, dan 3). Aspek ini terkonfirmasi saat wawancara kepada semua subjek. Sebagai contoh, S2 menguraikan respons, "Ada dua poin penting, 10.000 ekor penguin, jantan 5.000 dan betina 5.000. Setiap pasangan penguin memiliki 1 anak, jadi ada 15.000 penguin. Yang kedua, setiap akhir tahun sejumlah 20\% penguin mati."

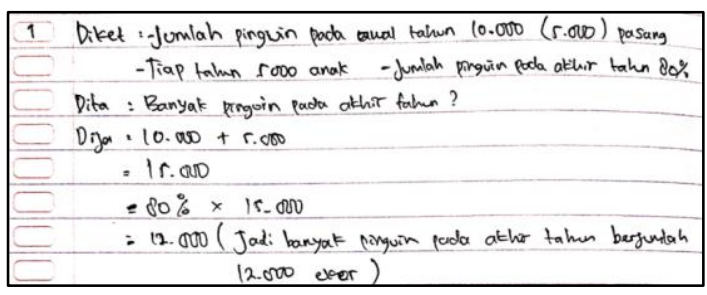

Gambar 1. Jawaban Tes S1 Soal 1 Penguin.
Adapun tentang aspek mathematising, ketiga subjek berhasil mengidentifikasi bilangan yang disajikan untuk mendapatkan total jumlah penguin. Ketiga subjek langsung menjumlahkan 10000 dengan 5000.

Lebih lanjut, aspek representation juga ditemui pada ketiga subjek meskipun terdapat perbedaan pilihan representasi yang digunakan. Bentuk persentase langsung dengan simbol \% digunakan oleh S1, sementara S2 memilih pecahan yang setara dengan persentase yang diketahui. Lain lagi dengan S3 yang membutuhkan dua representasi sekaligus yaitu persen yang kemudian diubah menjadi pecahan.

Dua aspek berikutnya berhubungan erat yaitu Reasoning and Argument dan Devising Strategies for Solving Problems. Ketiga subjek memiliki pendekatan dan strategi berbeda dalam menyelesaikan masalah di soal 1 . Siswa berkemampuan tinggi, S1, langsung menghitung $80 \%$ dari total penguin untuk mendapatkan jumlah penguin di akhir tahun.

Di sisi lain, S2 menghitung dulu penguin yang mati yaitu $20 \%$ sebelum mengurangkannya dari 15000 untuk mendapatkan jumlah penguin akhir. Sementara S3 perlu merinci proses hitungnya mulai dari menjumlahkan banyak penguin, melakukan pengurangan persen, mengubah persentase menjadi pecahan dan mengalikannya dengan banyak penguin. 


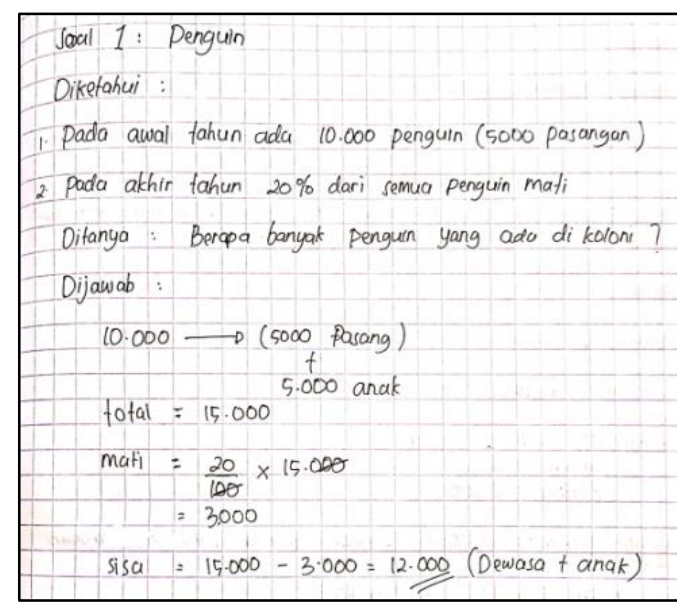

Gambar 2. Jawaban Tes S2 Soal 1 Penguin.

Pada sesi wawancara, S3 dengan jelas dan runtut menjelaskan prosesnya menemukan solusi, "pertama saya tambahkan 10.000 penguin dewasa dengan 5.000 anak penguin. Setelah itu kan ada $20 \%$ penguin akan mati, kan kalau seluruh penguin kan 100\% jadi itu 100\%$20 \%$, kemudian $10.000+5.000$ yang awal tadi itu saya kalikan dengan 100\%-20\%, 15.000 dikali 80\% hasilnya 12.000."

Berikutnya, dua aspek yaitu Using symbolic, Formal and Technical Language and Operations dan Using Mathematical Tools telah ditampakkan oleh ketiga subjek. Semua subjek berhasil memanfaatkan simbol dan melakukan operasi hitung dengan benar. Selain itu, temuan menarik didapatkan dari S3. Meskipun S3 berada di kategori siswa berkemampuan matematika rendah, S3 dengan mudah bisa mengubah situasi pada soal menjadi simbol matematika formal dengan sangat baik. $\mathrm{Hal}$ ini didapatkan saat wawancara seperti dikutip berikut.
$P \quad:$ Kalimat matematika apa yang cocok? Rumus apa yang cocok?

S2 : Perkiraan rumusnya seperti ini

$$
\left(a+\frac{1}{2} a\right)-\frac{20}{100} \times \frac{3}{2} a, a=10.000
$$

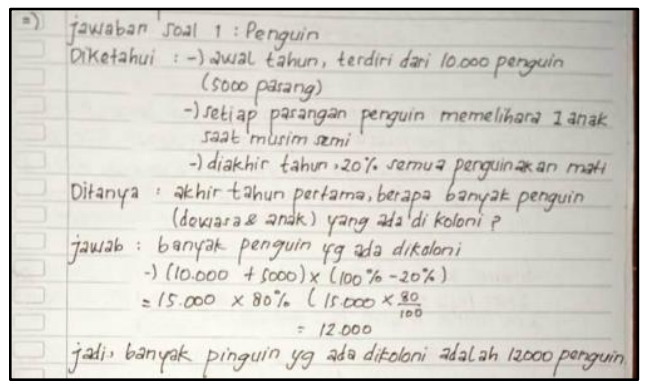

Gambar 3. Jawaban Tes S3 Soal 1 Penguin.

Berdasarkan uraian analisis jawaban dan wawancara kepada ketiga subjek tentang soal 1 penguin, dapat diinterpretasikan bahwa semua subjek memiliki pemahaman yang baik tentang konteks yang disajikan. Interpretasi ini didasarkan pada fakta bahwa setiap subjek memenuhi 7 kriteria pemahaman konteks. Konteks penguin pada soal nomor 1 memuat konten quantity dengan permintaan soal yang cenderung mudah. Selain itu, semua informasi pada konteks digunakan untuk menjawab masalah. Tidak ada informasi tambahan yang tidak digunakan sehingga siswa sama sekali tidak perlu menyeleksi informasi yang harus dipakai dalam menjawab soal.

Analisis berikutnya adalah tentang respon subjek penelitian terhadap soal nomor 2. Soal ini masih bermuatan konteks penguin. Siswa diminta memilih satu dari empat pilihan jawaban yang diberikan. Secara umum, ketiga subjek 
penelitian menjawab dengan benar soal ini. Namun, melalui jawaban tertulis dan konfirmasi saat wawancara, ketiga subjek menunjukkan perbedaan pemahaman tentang konteks yang diberikan.

Jawaban tertulis S1 menunjukkan bahwa informasi yang ditulis kembali adalah informasi dari soal nomor 1. Jumlah penguin langsung dimisalkan dengan $a$. Selain itu, tidak jelas bagaimana S1 memperoleh bilangan pengali $\frac{3}{2}$. Melalui wawancara, terkonfirmasi bahwa pecahan tersebut diperoleh dari pilihan jawaban yang semuanya memuat bilangan desimal 1,5. Sedangkan 0,8 diperoleh dari 80\%.

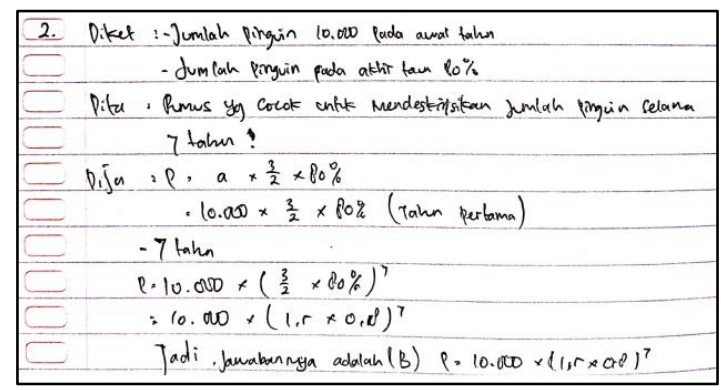

Gambar 4. Jawaban Tes S1 Soal 2 Penguin.

Sekalipun jawaban S1 benar, berdasarkan 7 aspek pemahaman konteks PISA siswa ini tidak memenuhi aspek communicating yang menuntut siswa membaca dan memilah informasi yang tepat ketika menyelesaikan masalah. Hal ini terjadi karena S1 keliru membaca informasi. Jadi, ketidakpahaman S1 kemungkinan karena kurang jeli membaca bahwa informasi di soal 1 dan soal 2 berbeda meskipun bercerita sama tentang penguin.
Selain S1 yang kurang teliti mencerna informasi, S3 menjawab soal 2 hanya dengan menebak jawaban. Meskipun S3 berhasil menuliskan kembali informasi pada soal 2, namun belum berhasil mengidentifikasi bahwa banyak penguin awal adalah 10000. Saat diwawancarai tentang mengapa memilih jawaban B, S3 menjawab, "Karena saya menyesuaikan dengan penjelasan dan pertanyaannya." S3 tidak memberikan justifikasi secara matematis. Karena itu, S3 hanya memenuhi aspek communicating saja.

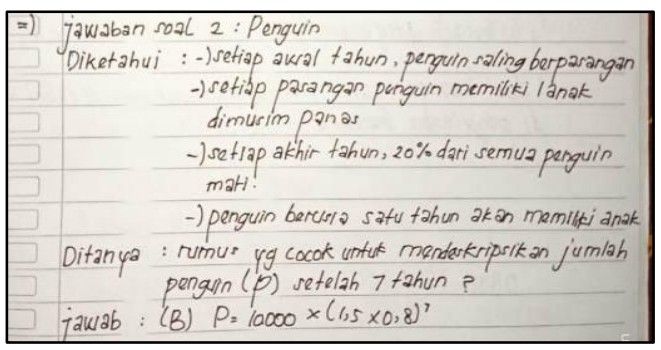

Gambar 5. Jawaban Tes S3 Soal 2 Penguin.

Subjek paling berhasil memahami dan mengolah informasi adalah S2. Jawaban tertulis S2 lengkap dengan penalaran pola untuk tahun pertama yang kemudian dipangkatkan 7 (lihat Gambar 6).

Berdasarkan informasi yang diberikan, S2 menghitung banyak penguin di akhir tahun pertama. S2 tidak paham bagaimana menggunakan informasi tentang penguin berusia 1 tahun akan memiliki anak. Oleh karena itu, S2 mencoba menghitung setiap pilihan yang diberikan untuk tahun pertama (pangkat 1). Dari uraian ini, dapat disimpulkan bahwa S2 memahami 
konteks namun memilih untuk menguji coba semua pilihan yang diberikan.

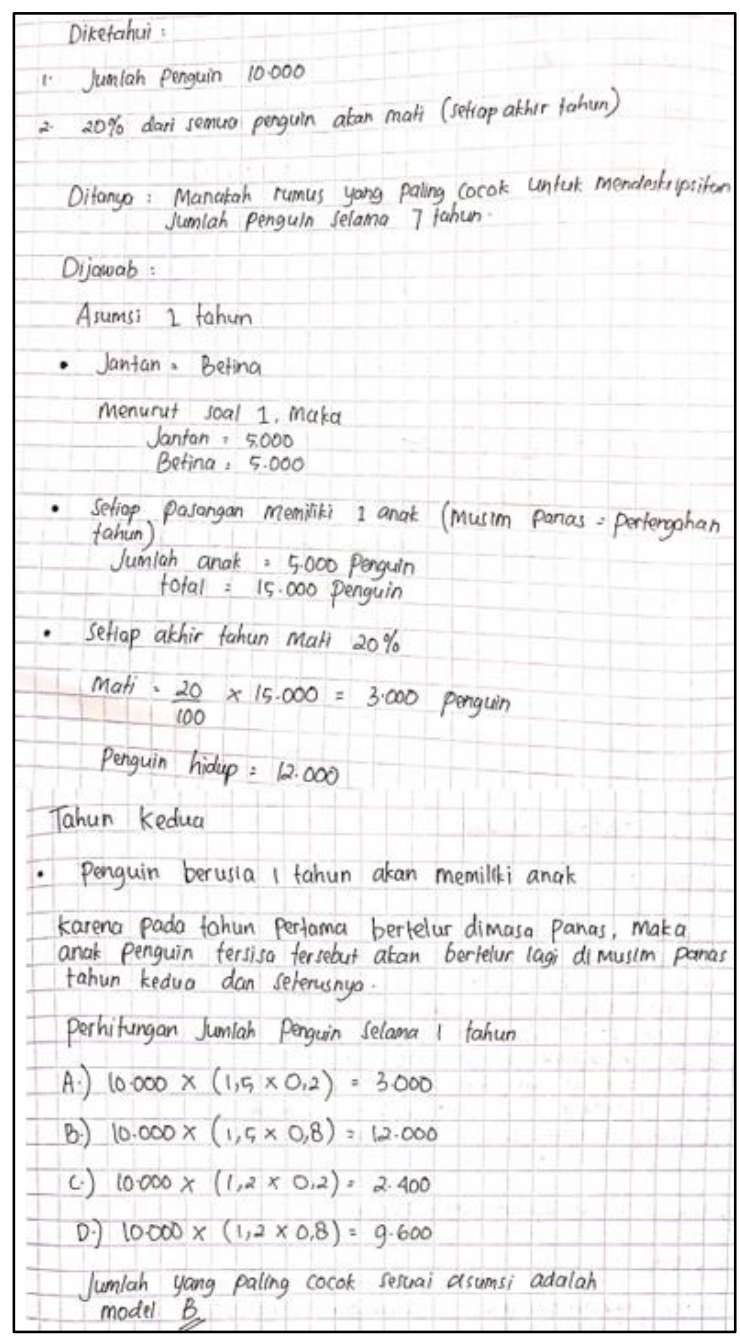

Gambar 6. Jawaban Tes S2 Soal 2 Penguin.

Berdasarkan analisis dari hasil tes maupun wawancara tentang soal 2 (Penguin), diperoleh bahwa pemahaman subjek tentang konteks belum menyeluruh. Hanya S2 yang menunjukkan penguasaan semua aspek pemahaman konteks meskipun kurang mencerna asumsi terakhir.

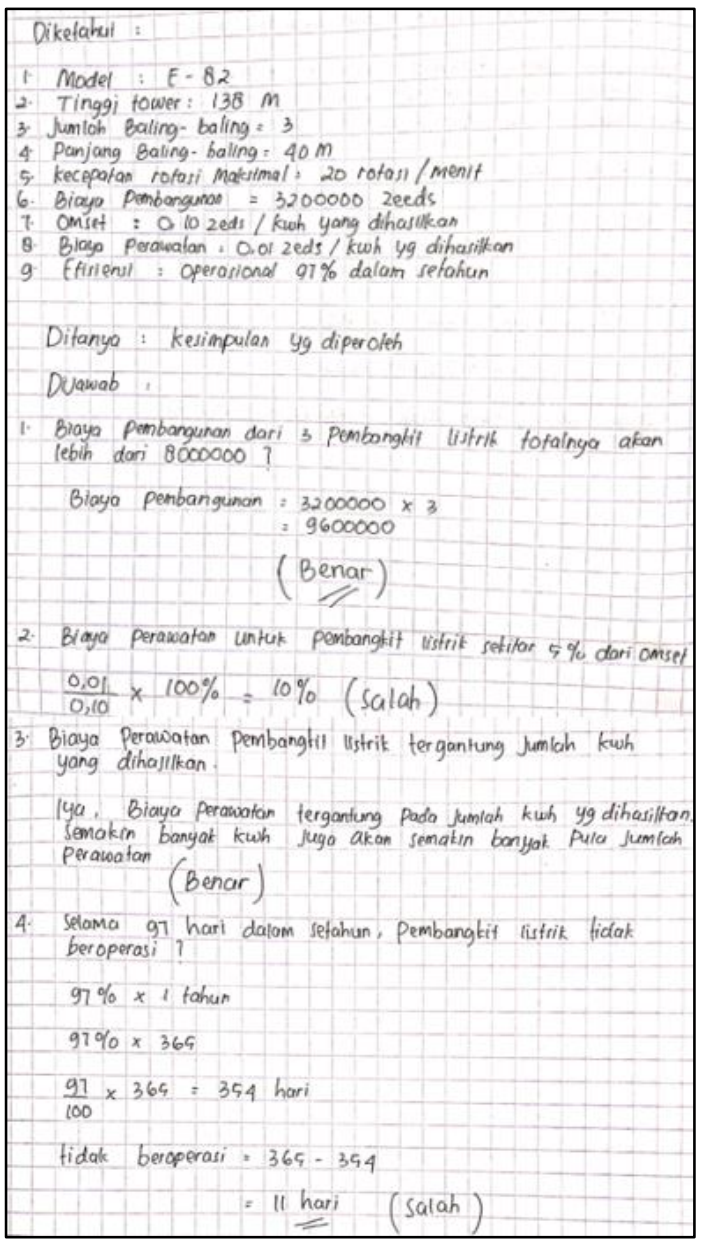

Gambar 7. Jawaban Tes S2 Soal 3 Pembangkit Tenaga Angin

Setelah pemaparan analisis pemahaman konteks di soal 1 dan 2, berikutnya akan dijelaskan hasil analisis untuk soal nomor 3 yaitu konteks Pembangkit Tenaga Angin. Pada konteks ini siswa disajikan informasi tentang nama model, ukuran baling-baling kincir, kecepatan rotasi, biaya, omset, dan tingkat efisiensi. Siswa kemudian diminta mengevaluasi 4 pernyataan dengan memilih BENAR atau SALAH.

Secara umum, ketiga subjek berhasil menjawab keempat soal dengan benar. 
Konfirmasi pemahaman siswa melalui wawancara menghasilkan temuan bahwa siswa tidak kesulitan mencerna informasi yang diberikan. Namun perbedaan kemampuan matematika antar subjek mungkin mempengaruhi kemampuan menjelaskan proses di aspek communicating. Selain S1, performa subjek S2 (lihat gambar 7) cukup baik ketika diminta menjelaskan informasi mana saja yang dibutuhkan seperti kutipan berikut.

"Tidak semuanya digunakan, hanya ada 4 yang digunakan yaitu: biaya pembangunan, omset, biaya perawatan, efisiensi. Yang tidak digunakan ada 5 yaitu: model, tinggi tower, jumlah balingbaling, panjang baling-baling, kecepatan rotasi maksimal."

Ketiga subjek juga menunjukkan kemampuan baik dalam memaknai representasi dan menggunakannya kembali. Salah satu contoh adalah ketika mengevaluasi pernyataan tentang biaya perawatan yang membutuhkan pemahaman tentang persen. Lebih lanjut, ketiga subjek dapat memenuhi semua aspek lain hingga menyelesaikan soal nomor 3.

Berdasarkan hasil analisis jawaban dan wawancara kepada siswa, ketiga subjek secara umum memenuhi tujuh kriteria pemahaman konteks. Namun saat menyelesaikan soal 2, hanya S2 yang berkemampuan sedang yang dapat mencerna informasi dan menyusun solusi dengan baik. Siswa S1 tidak memenuhi aspek communicating dan mathematising sebab keliru membaca informasi. Adapun pemahaman konteks yang dimiliki S3, yang merupakan siswa berkemampuan matematika rendah, sejalan dengan temuan Styawati \& Nursyahida (2017), Muzaki, \& Masjudin (2019), dan Masfufah \& Afriansyah (2021).

Penelitian ini memiliki kekurangan sebab wawancaranya terlalu singkat. Peneliti kurang dapat mengeksplorasi jalan pikiran subjek penelitian tentang konteks sebab konteks saintifik yang digunakan cukup sederhana. Peneliti menyarankan penelitian lanjutan dengan pemilihan konteks yang lebih kompleks sehingga dapat mengungkap sejauh mana siswa memahami dan menginterpretasi informasi. Jika dimungkinkan, wawancara dilakukan secara langsung bersamaan dengan siswa mengerjakan pemecahan masalah.

\section{Penutup}

Secara umum, siswa IPS yang diwakili oleh 3 subjek penelitian tidak menunjukkan adanya hambatan menyelesaikan soal PISA berkonteks saintifik. Dari 3 soal yang diberikan, semua dijawab dengan benar. Namun, literasi matematika khususnya terkait pemahaman konteks hanya tampak melalui 2 dari 3 soal. Dapat dikatakan bahwa siswa IPS memiliki tingkat pemahaman yang baik tentang konteks saintifik pada soal PISA sebab memenuhi hampir semua aspek pemahaman konteks, 
kecuali kesalahan minor salah membaca informasi untuk soal sebelumnya.

Jika ditinjau dari 7 aspek indikator penanda pemahaman konteks PISA, dua subjek penelitian tidak memenuhi ketujuh aspek hanya pada soal nomor 2 tentang penguin. Siswa berkemampuan matematika tinggi, S1, keliru membaca informasi sehingga yang disajikan kembali adalah konteks nomor 1 . Lain halnya dengan S3 (siswa berkemampuan matematika rendah) yang hanya menebak pilihan jawaban. Sangat mungkin interpretasi ini disebabkan kekurangan peneliti dalam mengungkap proses berpikir S3.

Hasil penelitian ini menunjukkan siswa IPS dapat memahami konteks PISA meskipun diberikan konteks saintifik. Penelitian berikutnya disarankan menggali lebih lanjut tentang pemahaman konteks saintifik oleh siswa IPS jika konten PISA yang diberikan berbeda dari yang disajikan di penelitian ini. Penelitian lanjutan juga disarankan untuk mengevaluasi literasi matematika siswa IPS menggunakan tinjauan kerangka kerja (framework) PISA tahun 2021 yang salah satu aspeknya adalah penalaran matematika (mathematical reasoning).

\section{Daftar Pustaka}

Dinni, H. N. (2018). HOTS (High Order Thinking Skills) dan Kaitannya dengan Kemampuan Literasi Matematika. PPRISMA, Prosidng Seminar Nasional Matematika, 1, 170-176.
Johar, R. (2012). Domain Soal Pisa untuk Literasi Matematika. Jurnal Peluang, 1(1), 30-41.

Junika, N., Izzati, N., \& Tambunan, L. R. (2020). Pengembangan Soal Statistika Model PISA untuk Melatih Kemampuan Literasi Statistika Siswa. Mosharafa: Jurnal Pendidikan Matematika, 9(3), 499-510.

Khoirudin, A., Dwi Styawati, R., \& Nursyahida, F. (2017). Profil Kemampuan Literasi Matematika Siswa Berkemampuan Matematis Rendah dalam Menyelesaikan Soal Berbentuk PISA. Aksioma, 8(2), 33-42. Maharani, D. A., \& Abadi, A. P. (2019). Kemampuan Literasi Matematis dan Kemampuan Berfikir Tingkat Tinggi Serta Kaitannya dengan Soal Matematika PISA. Prosiding Seminar Nasional Matematika Dan Pendidikan Matematika Sesiomadika 2019, 850857.

Masfufah, R., \& Afriansyah, E. A. (2021). Analisis Kemampuan Literasi Matematis Siswa melalui Soal PISA. Mosharafa: Jurnal Pendidikan Matematika, 10(2), 291-300.

Merpaung, Y. (2006). Karakteristik PMRI (Pendidikan Matematika Realistik Indonesia). Journal on Mathematics Education, 1(1), 1-10.

Muzaki, A., \& Masjudin. (2019). Analisis Kemampuan Literasi Matematis Siswa. Mosharafa, 8(3), 493-502.

Noviana, K. Y., \& Murtiyasa, B. (2020). Kemampuan Literasi Matematika 
Berorientasi PISA Konten Quantity

Pada Siswa SMP. JNPM (Jurnal

Nasional Pendidikan Matematika), 4(2), 195-211.

OECD. (2001). Literacy Skills for the World of Tomorrow. In OECD (1st ed.). OECD.

OECD. (2004). Learning for Tomorrow's World: First Results from PISA 2003. In OECD (1st ed.). OECD.

OECD. (2007). The Programme for International Student Assessment (PISA). In OECD (1st ed.). OECD.

OECD. (2010). PISA 2009 Results: What Students Know and Can Do. In OECD (1st ed.). OECD.

OECD. (2013a). PISA 2012 Relased Mathematics Items. In OECD (1st ed.). OECD.

OECD. (2013b). PISA 2012 Results in Focus. In OECD (1st ed.). OECD.

OECD. (2016). PISA 2015 Result in Focus. In OECD (1st ed.). OECD.

OECD. (2019a). PISA 2018 Assessment and Analytical Framework. In OECD (1st ed.). OECD.

OECD. (2019b). PISA 2018 Result. In OECD: Vol. 1,2,3 (1st ed.). OECD.

OECD. (2019c). What is PISA? In PISA 2018 Assessment and Analytical Framework (1st ed., pp. 11-19). OECD.

Prabawati, M. N. (2018). Analisis Kemampuan Literasi Matematika Mahasiswa Calon Guru Matematika. Mosharafa, 7(1), 113-120.

Pratiwi, I. (2019). Efek Program PISA terhadap Kurikulum di Indonesia.
Jurnal Pendidikan Dan Kebudayaan, 4(1), 51-71.

Puspitasari, A. (2015). Analisis Kemampuan Literasi Matematika Kelas X MIPA 5 SMA Negeri 1 Ambulu Berdasarkan Kemampuan Matematika [Universitas Jember]. In Universitas Jember.

Wicaksana, Y., Wardono, \& Ridlo, S. (2017). Analisis Kemampuan Literasi Matematika dan Karakter Rasa Ingin Tahu Siswa pada Pembelajaran Berbasis Proyek Berbantuan Schoology. Unnes Journal of Mathematics Education Research, 6(2), 167-174.

\section{Riwayat Hidup PENUlis Bagus Wahyu Purnomo.}

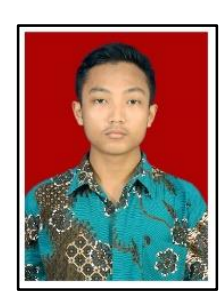

Lahir di Sidoarjo, 27 Agustus 1999. Mahasiswa Program Studi S1 Pendidikan Matematika, STKIP Al Hikmah Surabaya.

Anisa Fatwa Sari, S.Pd., M.Sc.

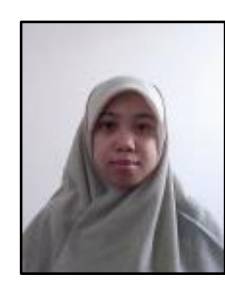

Staf pengajar di STKIP Al Hikmah Surabaya. Studi S1 Pendidikan Matematika di Universitas Negeri Surabaya (Unesa) lulus tahun 2010; S2 melalui program IMPoME kerja sama Unesa dan Freudenthal Institute, Utrecht University, lulus tahun 2012. 